\title{
Interaction between Pirenzepine and Ninjinto, a Traditional Japanese Herbal Medicine, on the Plasma Gut-Regulated Peptide Levels in Humans
}

\author{
Yuhki Sato, Itoh Hiroki, Yosuke Suzuki, Ryosuke Tatsuta, and Masaharu Takeyama \\ Department of Pharmacy, Oita University Hospital, 1-1 Idaigaoka, Hasama-Machi, Oita 879-5593, Japan \\ Correspondence should be addressed to Yuhki Sato; syuhki@oita-u.ac.jp
}

Received 26 November 2012; Revised 11 February 2013; Accepted 5 March 2013

Academic Editor: Eva Ekblad

Copyright (C) 2013 Yuhki Sato et al. This is an open access article distributed under the Creative Commons Attribution License, which permits unrestricted use, distribution, and reproduction in any medium, provided the original work is properly cited.

\begin{abstract}
The Japanese herbal medicine (Kampo) Ninjinto has been used for the treatment of gastroenteritis, esogastritis, gastric atony, gastrectasis, vomiting, and anorexia. The pharmacological effects of Ninjinto on the gastrointestine are due to changes in the levels of gut-regulated peptide, such as motilin, somatostatin, calcitonin gene-related peptide (CGRP), substance P, and vasoactive intestinal polypeptide (VIP). The release of these peptides is controlled by acetylcholine (ACh) from the preganglionic fibers of the parasympathetic nerve. Thus, we examined the effects of the selective $\mathrm{M}_{1}$ muscarinic receptor antagonist pirenzepine on the elevation of Ninjinto-induced plasma the area under the plasma gut-regulated peptide concentration-time curve from 0 to $240 \mathrm{~min}$ $\left(\mathrm{AUC}_{0 \rightarrow 240 \mathrm{~min}}\right)$ in humans. Oral pretreatment with pirenzepine significantly reduced the Ninjinto-induced elevation of plasma motilin and substance $\mathrm{P}$ release $\left(\mathrm{AUC}_{0 \rightarrow 240 \mathrm{~min}}\right)$. Combined treatment with Ninjinto and pirenzepine significantly increased the release of plasma somatostatin $\left(\mathrm{AUC}_{0 \rightarrow 240 \mathrm{~min}}\right)$ compared with administration of Ninjinto alone or placebo. Ninjinto appeared to induce the release of substance $P$ and motilin into plasma mainly through the activation of $M_{1}$ muscarinic receptors, and pirenzepine may affect the pharmacologic action of Ninjinto by the elevation of plasma substance P, motilin, and somatostatin.
\end{abstract}

\section{Introduction}

Kampo medicines, traditional herbal medicines, have been employed for a few thousand years and have contributed greatly to the treatment of many subjective symptoms. Kampo medicines are frequently prescribed with other synthetic or biotechnological drugs for the treatment of various chronic diseases. Such herbal medicines have been used in China for thousands of years and are now being manufactured in Japan as drugs. Most Kampo medicines are prepared from multiple crude herbs and contain many unrefined substances, and to determine the precise mechanism of the pharmacological effects of these medicines is too difficult. Ninjinto, a traditional Japanese Kampo medicine, is prepared from four different Chinese crude drugs. This medicine is one of the major prescriptions most frequently used for treatment of gastroenteritis, esogastritis, gastric atony, gastrectasis, vomiting, and anorexia in Japan. Al previous study has shown that Ninjinto not only significantly improved gastrointestinal motility but also showed stronger effects than those of some prokinetic drugs such as cisapride and metoclopramide in a rat model of postoperative ileus [1]. Hence, Ninjinto may be an effective herbal medicine for postoperative ileus.

One of the factors regulating gastrointestinal function has been suggested to be induction of changes in plasma levels of peptides such as motilin, somatostatin, calcitonin generelated peptide (CGRP), and substance P. In recent years, some Kampo medicines of experimental gastrointestinal effects have been elucidated pharmacologically from the viewpoint of gut-regulated peptide levels. Among these reports, Naito et al. [2] previously confirmed that Ninjinto increased the levels of motilin, a powerful inducer of gastrointestinal motor activity and somatostatin, and that it participates in the control of gut motility by exerting both inhibitory and stimulating influences in human plasma. We also reported that Ninjinto increased the levels of cytoprotective peptides, CGRP, and substance P [3]. These results indicate that the action of Ninjinto is closely related to 
changes in motilin, somatostatin, CGRP, and substance P levels in plasma.

Nervous mechanisms are important for the regulation of gastrointestinal motility and blood flow. A number of gutregulated peptides such as CGRP and substance $P$ have been localized immunohistochemically in nerves innervating the gastrointestinal tract [4]. The release of these peptides is controlled by acetylcholine (ACh) from the preganglionic fibers of the parasympathetic nerve [5-7]. Muscarinic receptors are also present on the membrane of motilin-secreting cells, and ACh is a major regulator of motilin release in the gastrointestine [8-11].

Pirenzepine, an antagonist specific for muscarinic $M_{1}$ receptors, suppresses acid output and is used to treat gastritis and peptic ulcers clinically [12]. It has also been shown that this drug suppresses the elevation of serum gastrin levels by acting directly or indirectly on gastrin cells (G cells) $[13,14]$. In clinical therapy, pirenzepine is often coadministered with Ninjinto. It is therefore of interest to examine the effects of pirenzepine on pharmacological action of Ninjinto release from the viewpoint of plasma gut-regulated peptide levels.

The purpose of this study was to examine the effects of pirenzepine on the area under the plasma concentration-time curve from 0 to $240 \mathrm{~min}\left(\mathrm{AUC}_{0 \rightarrow 240 \mathrm{~min}}\right)$ of Ninjinto-induced elevation of plasma CGRP-, substance-P-, motilin-, somatostatin-, and vasoactive-intestinal-polypeptides- (VIPs) immunoreactive substance (IS) in humans.

\section{Materials and Methods}

2.1. Materials. Ninjinto (EK-32, lot 01BJ), prepared as a $2.8 \mathrm{~g}$ dried powder extract in the proportion Ginseng radix $(3.0 \mathrm{~g})$, Glycyrrhizae radix (3.0 g), Atractylodis rhizoma (3.0 g), Zingiberis siccatum rhizoma (3.0 g), was kindly supplied by Kanebo Co. Ltd. (Tokyo, Japan). Pirenzepine (Gastrozepine tablet) was purchased from Boehringer Ingelheim Co. Ltd. (Hyogo, Japan). The VIP fragment peptide was supplied by Professor H. Yajima (Kyoto University, Kyoto, Japan). Antisera to VIP (A6054/R1B) and CGRP (CA1132) were purchased from Biogenesis (Poole, UK). Antisera to somatostatin (RA-08-108) and substance P (RA-08-095) were purchased from Cambridge Research Biochemicals (Cambridge, UK), and antiserum to motilin (Y121) was purchased from the Yanaihara Institute (Shizuoka, Japan). All other reagents were of analytical grade from commercial sources.

2.2. Subjects. Five healthy male volunteers (nonsmokers), aged 26-29 (median 27) years, weighing 55-68 (median weight 62$) \mathrm{kg}$, with no history of gastrointestinal or hepatobiliary disease, and not taking any regular medications, participated in this study. No volunteers had received any medication for 1 month before the study, and there were at least 3-month intervals between participation in other studies. The volunteers had participated in more than three similar studies.

2.3. Ethics. Each subject received information about the scientific purpose of the study, which was approved by the Ethics
Committee of Oita Medical University, and gave informed consent for participation.

2.4. Study Schedule. Ninjinto or placebo (crystalline cellulose and lactose) was administered orally alone or $60 \mathrm{~min}$ after oral administration of pirenzepine $75 \mathrm{mg}$ as a single dose of $6.0 \mathrm{~g}$ with water. The dose of test drugs used in this study was the maximum daily dose used in clinical therapy. For the same volunteers, pirenzepine $(75 \mathrm{mg}$ ) or placebo (lactose capsules) was administered orally with $100 \mathrm{~mL}$ water. Each study was carried out with an interval of four weeks. Venous blood samples $(10 \mathrm{~mL})$ from a forearm vein were taken for enzyme immunoassay (EIA) of the levels of gut-regulated peptide. Samples were taken before and at 20, 40, 60, 90, 120,180 , and $240 \mathrm{~min}$ after administration of the drugs. All volunteers ate lunch (11:30-12:00) and the study was carried out from 14:00 (120 min after lunch) to 18:00.

2.5. Preparation of Plasma Extracts. The blood samples were collected in a chilled tube containing aprotinin (500kallikrein inhibitor units $/ \mathrm{mL}$ ) and ethylenediaminetetraacetic acid (EDTA) $(1.2 \mathrm{mg} / \mathrm{mL})$. After centrifugation, the plasma samples were diluted with $4 \%$ acetic acid $(\mathrm{pH} \mathrm{4.0)}$, loaded onto Sep-Pak $\mathrm{C}_{18}$ cartridges (Millipore Corp., Milford, USA), and washed with $4 \%$ acetic acid. The peptides in the plasma were eluted with $70 \%$ acetonitrile in $0.5 \%$ acetic acid ( $\mathrm{pH} 4.0$ ), lyophilized, and reconstituted to $100 \mu \mathrm{L}$ with the assay buffer and subjected to EIA. For the EIA system, plasma samples were concentrated fivefold with Sep-Pak $\mathrm{C}_{18}$ cartridges. The recovery of plasma CGRP-, substanceP-, VIP-, motilin-, and somatostatin-IS was $>90 \%$ with this extraction procedure.

2.6. EIA Procedure of CGRP, Substance P, VIP, Motilin, and Somatostatin. EIAs for CGRP- [15], substance-P- [16], VIP[17], motilin- [18], and somatostatin-IS [19] were performed as previously described, by a delayed-addition method [20]. Separation of bound and free antigens was performed on an anti-rabbit IgG-coated immunoplates. The fluorescent product 4-methylumbelliferone was measured with an MTP100F microplate reader (Corona Electric, Ibaraki, Japan). Human somatostatin, porcine motilin, fragment VIP (11-28), human CGRP (8-37), and substance $P$ were conjugated with $\beta^{-}{ }$-galactosidase (Boehringer Mannheim, Mannheim, Germany) with $N$-( $\varepsilon$-maleimidocaproyloxy)-succimide according to the method of Kitagawa et al. [21]. The EIAs for somatostatin, motilin, VIP, CGRP, and substance P were specific and highly sensitive to detection limits of $0.10,0.80$, $1.00,0.08$, and $0.40 \mathrm{fmol} /$ well, respectively.

2.7. Data Analysis. Total release of peptides was calculated as the areas under the plasma concentration-time curves $\left(\mathrm{AUC}_{0 \rightarrow 240 \mathrm{~min}}\right)$ using the trapezoidal method. All values are expressed as mean \pm s.d. $(\mathrm{pg} / \mathrm{mL})$. Comparisons of plasma peptide levels among blood sampling times were analyzed using Friedmann's test followed by the Mann-Whitney $U$ test. Value of $P<0.01$ or $P<0.05$ was considered to represent a statistically significant difference. 
TABLE 1: Total amount of substance-P-, CGRP-, and VIP-IS released in plasma after the administration of Ninjinto (6.0 g) to 5 healthy volunteers with or without pirenzepine $(75 \mathrm{mg})$ treatment.

\begin{tabular}{lccc}
\hline & & Plasma $\mathrm{AUC}_{0 \rightarrow 240 \mathrm{~min}}(\mathrm{pg} \mathrm{mL} / \mathrm{min})$ & \\
& Ninjinto $(6.0 \mathrm{~g})$ & Ninjinto $(6.0 \mathrm{~g})+$ pirenzepine $(75 \mathrm{mg})$ & $5187.0 \pm 964.9$ \\
\hline CGRP & $7937.7 \pm 2485.9^{*}$ & $7497.7 \pm 2465.2$ & $5104.5 \pm 1091.1$ \\
Substance P & $9815.0 \pm 2182.7$ & $4313.2 \pm 1226.4^{\dagger}$ & $20481.0 \pm 5693.6$ \\
Motilin & $28360.0 \pm 3017.4$ & $11997.4 \pm 2483.2^{* * \dagger}$ & $1928.7 \pm 122.9$ \\
Somatostatin & $2870.0 \pm 512.1^{*}$ & $3016.2 \pm 462.1^{* *}$ & $2011.2 \pm 298.7$ \\
VIP & $2005.9 \pm 793.4$ & $2004.2 \pm 915.1$ & \\
\hline
\end{tabular}

Each value represents the mean \pm s.d. $n=5$. $\mathrm{AUC}_{0 \rightarrow 240 \mathrm{~min}}$, area under the plasma concentration-time curve from 0 to 240 min. ${ }^{*} P<0.05$ and ${ }^{* *} P<0.01$ significantly different compared with placebo. ${ }^{\dagger} P<0.05$ significantly different compared with Ninjinto alone.

TABLE 2: Total amount of CGRP-, substance-P-, motilin-, somatostatin-, and VIP-IS released in plasma after the administration of pirenzepine $(75 \mathrm{mg})$ to 5 healthy volunteers.

\begin{tabular}{lcc}
\hline & \multicolumn{2}{c}{ Plasma $\mathrm{AUC}_{0 \rightarrow 240 \mathrm{~min}}(\mathrm{pg} \mathrm{mL} / \mathrm{min})$} \\
& Pirenzepine $(75 \mathrm{mg})$ & Placebo \\
\hline CGRP & $8864.9 \pm 1581.8^{* *}$ & $6306.6 \pm 542.0$ \\
Substance P & $2979.4 \pm 1350.0$ & $5104.5 \pm 1091.1$ \\
Motilin & $14010.7 \pm 9483.4$ & $20481.0 \pm 5693.6$ \\
Somatostatin & $4779.3 \pm 858.5^{*}$ & $3483.8 \pm 345.7$ \\
VIP & $1645.6 \pm 551.5$ & $2011.2 \pm 298.7$ \\
\hline
\end{tabular}

Each value represents the mean \pm s.d. $n=5 . \mathrm{AUC}_{0 \rightarrow 240 \mathrm{~min}}$, area under the plasma concentration-time curve from 0 to 240 min. ${ }^{*} P<0.05$ and ${ }^{* *} P<$ 0.01 significantly different compared with placebo.

\section{Results}

3.1. Changes of the Release of Plasma CGRP-, Substance-P-, Motilin-, Somatostatin-, and VIP-IS $\left(A U C_{0 \rightarrow 240 \mathrm{~min}}\right)$ after Ninjinto, with or without Pirenzepine Pretreatment. The total release of plasma CGRP-, substance-P-, motilin-, somatostatin-, and VIP-IS $\left(\mathrm{AUC}_{0 \rightarrow 240 \mathrm{~min}}\right.$ ) after administration of Ninjinto, with or without pirenzepine pretreatment is shown in Table 1. The total release of CGRP $\left(\mathrm{AUC}_{0 \rightarrow 240 \mathrm{~min}}\right)$ increased significantly after administration of Ninjinto (7937.7 \pm $2485.9 \mathrm{pg} \mathrm{mL} / \mathrm{min}$ ) compared with placebo $(5187.0 \pm 964.9$ $\mathrm{pg} \mathrm{mL} / \mathrm{min}$ ) but did not change after the administration of Ninjinto with pirenzepine pretreatment $(7949.7 \pm 2465.2$ $\mathrm{pg} \mathrm{mL} / \mathrm{min})$. The total release of substance $\mathrm{P}\left(\mathrm{AUC}_{0 \rightarrow 240 \mathrm{~min}}\right)$ after administration of Ninjinto with pirenzepine pretreatment $(4313.2 \pm 1226.4 \mathrm{pg} \mathrm{mL} / \mathrm{min})$ significantly decreased compared with Ninjinto alone $(9815.0 \pm 2182.7 \mathrm{pg} \mathrm{mL} / \mathrm{min})$. The total release of motilin $\left(\mathrm{AUC}_{0 \rightarrow 240 \mathrm{~min}}\right)$ after administration of Ninjinto alone $(28360.0 \pm 3017.4 \mathrm{pg} \mathrm{mL} / \mathrm{min})$ significantly increased but decreased after administration of Ninjinto with pirenzepine pretreatment $(11997.4 \pm 2483.2$ $\mathrm{pg} \mathrm{mL} / \mathrm{min}$ ), compared with Ninjinto alone and placebo group $(20481.0 \pm 5693.6 \mathrm{pg} \mathrm{mL} / \mathrm{min})$. The total release of motilin $\left(\mathrm{AUC}_{0 \rightarrow 240 \mathrm{~min}}\right)$ decreased after the administration of Ninjinto with pirenzepine pre-treatment (11997.4 \pm $2483.2 \mathrm{pg} \mathrm{mL} / \mathrm{min}$ ), compared with Ninjinto alone and placebo (28360.0 \pm 3017.4 and $20481.0 \pm 5963.6 \mathrm{pg} \mathrm{mL} / \mathrm{min}$, resp.). After the administration of Ninjinto with or without pirenzepine pretreatment, no significant changes were observed in the total release of VIP $\left(\mathrm{AUC}_{0 \rightarrow 240 \mathrm{~min}}\right)$.
3.2. Changes of the Release of Plasma CGRP-, Substance-P-, Motilin-, Somatostatin-, and VIP-IS Levels after Pirenzepine. The total releases of CGRP, substance-P-, motilin-, somatostatin-, and VIP $\left(\mathrm{AUC}_{0 \rightarrow 240 \mathrm{~min}}\right)$ after administration of pirenzepine are shown in Table 2. The total release of CGRP $\left(\mathrm{AUC}_{0 \rightarrow 240 \mathrm{~min}}\right)$ increased after administration of pirenzepine $(8864.9 \pm 1581.8 \mathrm{pg} \mathrm{mL} / \mathrm{min})$ compared with placebo $(6306.6 \pm 542.0 \mathrm{pg} \mathrm{mL} / \mathrm{min})$. After the administration of pirenzepine, no significant changes were observed in the total release of substance-P $\left(\mathrm{AUC}_{0 \rightarrow 240 \mathrm{~min}}\right)$. The total release of somatostatin $\left(\mathrm{AUC}_{0 \rightarrow 240 \mathrm{~min}}\right)$ significantly increased after administration of pirenzepine (4779.3 \pm $858.5 \mathrm{pg} \mathrm{mL} / \mathrm{min}$ ) compared with placebo group (3483.8 \pm $345.7 \mathrm{pg} \mathrm{mL} / \mathrm{min}$ ). After the administration of pirenzepine, no significant changes were observed in the total release of VIP $\left(\mathrm{AUC}_{0 \rightarrow 240 \mathrm{~min}}\right)$.

\section{Discussion}

In our study, Ninjinto significantly increased the release of plasma CGRP, substance P, motilin, and somatostatin. The coadministration of Ninjinto with pirenzepine pretreatment significantly decreased the release of plasma substance $\mathrm{P}$ and motilin and increased that of plasma somatostatin compared with Ninjinto alone or placebo.

CGRP is a powerful vasoactive substance that is released from the sensory afferent nerve endings in response to gastric mucosal injury in the stomach. CGRP increases gastric mucosal blood flow as a gastroprotective factor [22]. In addition, CGRP has a potent effect on gastrointestinal motility and secretion [23]. In our study, Ninjinto significantly raised the releases of plasma CGRP after administration to healthy volunteers, while Ninjinto with pirenzepine pretreatment had not changed compared with Ninjinto alone and placebo. Previous studies demonstrated that CGRP is localized in motor neurons and nerve terminals at the neuromuscular junction, where it coexists with ACh and that CGRP is a neurotransmitter that may act in conjunction with Ach [24]. Trasforini et al. [6] reported that the acetylcholinesterase inhibitor caused significant increases in basal plasma levels of CGRP in healthy humans, whereas pirenzepine failed to exert any significant effect. Thus, it was thought that the effects of Ninjinto on CGRP levels might be not related in $\mathrm{M}_{1}$ muscarinic receptor. 
Substance P coexists with CGRP in the sensory afferent neurons of the gastrointestinal mucosa and is released with $\mathrm{ACh}$ in response to depolarizing stimulation in the enteric nervous system [25]. In the gastrointestinal tract, substance $\mathrm{P}$ is thought to be involved in the control of motility, secretion, and blood flow [26]. In our study, Ninjinto raised the release of plasma substance $\mathrm{P}$ after administration to healthy volunteers, while that after the administration of Ninjinto with pirenzepine pretreatment caused decreases compared with Ninjinto alone or placebo. Schmidt and Holst [27] reported that muscarinic receptors are present on the intrinsic substance-P-producing neurons and inhibit the release of substance $\mathrm{P}$ in porcine ileum. Although it has not previously been confirmed whether $M_{1}$ muscarinic receptors are present on the substance-P-producing neurons in gastrointestinal tract, these results indicate that the effects of Ninjinto on plasma substance P levels might be related to $\mathrm{M}_{1}$ muscarinic receptor.

Motilin is one of the most important factors controlling the regular occurrence of phase III of interdigestive migrating contractions [28]. Muscarinic receptors are present on the membrane of motilin-secreting cells, and ACh is a major regulator of motilin release by acting on $M_{1}$ or $M_{3}$ muscarinic receptors. In our results, the administration of Ninjinto with pirenzepine pretreatment decreased the release of plasma motilin compared with Ninjinto alone. Thus, it is thought that the effect of Ninjinto on the release of plasma motilin might be blocked by the administration of pirenzepine. Also, it is known that somatostatin inhibits the secretion of motilin in gut [29]. Pirenzepine-elevated somatostatin might be closely related to part of decreases in plasma motilin levels. Our findings suggest that Ninjinto may stimulate motilin cells mainly via $\mathrm{M}_{1}$ muscarinic receptors.

Somatostatin is a gastrointestinal motility stimulator and functions as an inhibitor of motilin and gastrin release in digestive organs [30]. In our results, the administration of Ninjinto with pirenzepine pretreatment significantly increased the release of plasma somatostatin compared with placebo. Sue et al. [14] reported that pirenzepine acts on somatostatin cells (D cells) to promote somatostatin release, thereby indirectly suppressing gastrin release from $\mathrm{G}$ cells in the stomach. In our study, pirenzepine significantly increased the release of plasma somatostatin. These results show that the effects of Ninjinto with pirenzepine pretreatment on plasma somatostatin may be related to direct or indirect action by Ninjinto and pirenzepine.

VIP has a vasodilating effect and is a gastrointestinal motility regulator. VIP is considered to be one of the neurotransmitters released from nonadrenergic, noncholinergic inhibitory neurons in the gastrointestinal tract [31]. We found that Ninjinto with or without pirenzepine pretreatment had no effect on plasma VIP-IS levels.

According to the report by Sekiya and Morimoto [1], Ninjinto significantly might increase plasma gut-regulated peptide levels in the treatment of diseases of the ileus and its changes might contribute to promoting gastrointestinal motility. Therefore, the pharmacological action of Ninjinto might be partially due to the changes in plasma gut-regulated peptides. In our results, the coadministration of Ninjinto with pirenzepine pretreatment caused a significant decrease in plasma substance $\mathrm{P}$, motilin, and somatostatin releases, compared with Ninjinto alone or placebo. It was estimated that the use of pirenzepine might affect the clinical efficacy of Ninjinto, although it is certain whether these effects in healthy volunteers are the same as those in patients clinically. Therefore, it is necessary to investigate the effects in patients with a condition such as ileus.

\section{Conclusions}

Ninjinto might increase the release of plasma substance $\mathrm{P}$ and motilin via $\mathrm{M}_{1}$ muscarinic receptors. Coadministration of Ninjinto with pirenzepine decreases Ninjinto-induced substance $\mathrm{P}$ and motilin release and increases that of somatostatin release. But CGRP and VIP have no changes. Although further studies are needed, our findings may be important clinically.

\section{References}

[1] M. Sekiya and Y. Morimoto, "Effect of several Kampo medicines on postoperative ileus model," The Japan Jounal of Oriental Medicine, vol. 54, pp. 785-790, 2003.

[2] T. Naito, H. Itoh, T. Nagano, and M. Takeyama, "Effects of Ninjin-to on levels of brain-gut peptides (Motilin, vasoactive intestinal peptide, gastrin, and somatostatin) in human plasma," Biological and Pharmaceutical Bulletin, vol. 24, no. 2, pp. 194196, 2001.

[3] Y. Sato, F. Katagiri, S. Inoue, H. Itoh, and M. Takeyama, "Daikenchu-to raises levels of calcitonin gene-related peptide and substance $\mathrm{P}$ in human plasma," Biological and Pharmaceutical Bulletin, vol. 27, no. 11, pp. 1875-1877, 2004.

[4] I. L. Gibbins, J. B. Furness, and M. Costa, "Pathway-specific patterns of the co-existence of substance $\mathrm{P}$, calcitonin generelated peptide, cholecystokinin and dynorphin in neurons of the dorsal root ganglia of the guinea-pig," Cell and Tissue Research, vol. 248, no. 2, pp. 417-437, 1987.

[5] H. Kimura, S. Ito, T. Ohta, T. Asano, and Y. Nakazato, "Vasoactive intestinal peptide released by acetylcholine in the dog ileum," Journal of the Autonomic Nervous System, vol. 48, no. 2, pp. 167-174, 1994.

[6] G. Trasforini, A. Margutti, L. Vergnani et al., "Evidence that enhancement of cholinergic tone increases basal plasma levels of calcitonin gene-related peptide in normal man," Journal of Clinical Endocrinology and Metabolism, vol. 78, no. 3, pp. 763766, 1994.

[7] P. T. Schmidt and J. J. Holst, "Use of antagonists to define tachykininergic control of intestinal motility in pigs," Peptides, vol. 18, no. 3, pp. 373-379, 1997.

[8] J. E. T. Fox, E. E. Daniel, J. Jury, N. S. Track, and S. Chiu, "Cholinergic control mechanisms for immunoreactive motilin release and motility in the canine duodenum," Canadian Journal of Physiology and Pharmacology, vol. 61, no. 9, pp. 1042-1049, 1983.

[9] D. K. Nelson, O. Pieramico, G. Dahmen, J. E. DominguezMunoz, P. Malfertheiner, and G. Adler, "M1-muscarinic mechanisms regulate interdigestive cycling of motor and secretory activity in human upper gut," Digestive Diseases and Sciences, vol. 41, no. 10, pp. 2006-2015, 1996. 
[10] P. Poitras, A. Dumont, J. C. Cuber, and L. Trudel, "Cholinergic regulation of motilin release from isolated canine intestinal cells," Peptides, vol. 14, no. 2, pp. 207-213, 1993.

[11] T. Yamada, A. Mizumoto, M. Satoh, N. Haga, and Z. Itoh, "Muscarinic control of phase III contractions and motilin release in dogs," Peptides, vol. 18, no. 5, pp. 673-680, 1997.

[12] R. Hammer, C. P. Berrie, and N. J. M. Birdsall, "Pirenzepine distinguishes between different subclasses of muscarinic receptors," Nature, vol. 283, no. 5742, pp. 90-92, 1980.

[13] Y. Matsuo and A. Seki, "Actions of pirenzepine dihydrochloride (LS $519 \mathrm{Cl}$ ) on gastric juice secretion, gastric motility and experimental gastric ulcer," Arzneimittelforschuang, vol. 29, no. 7, pp. 1028-1035, 1979.

[14] R. Sue, M. L. Toomey, A. Todisco, A. H. Soll, and T. Yamada, "Pirenzepine-sensitive muscarinic receptors regulate gastric somatostatin and gastrin," The American Journal of Physiology, vol. 248, no. 2, pp. G184-G187, 1985.

[15] T. Nagano, K. Ikawa, and M. Takeyama, "Enzyme immunoassay of calcitonin gene-related peptide-like immunoreactive substance in human plasma and saliva," The Japanese Journal of Hospital Pharmacy, vol. 24, pp. 363-369, 1998.

[16] M. Takeyama, K. Mori, F. Takayama, K. Kondo, K. Kitagawa, and N. Fujii, "Enzyme immunoassay of a substance P-like immunoreactive substance in human plasma and saliva," Chemical and Pharmaceutical Bulletin, vol. 38, no. 12, pp. 3494-3496, 1990.

[17] M. Takeyama, K. Wakayama, F. Takayama, K. Kondo, N. Fujii, and H. Yajima, "Micro-enzyme immunoassay of vasoactive intestinal polypeptide (VIP)-like immunoreactive substance in bovine milk," Chemical and Pharmaceutical Bulletin, vol. 38, no. 4, pp. 960-962, 1990.

[18] T. Naito, H. Itoh, F. Yasunaga, and M. Takeyama, "Hangeshashin-to raises levels of somatostatin, motilin, and gastrin in the plasma of healthy subjects," Biological and Pharmaceutical Bulletin, vol. 25, no. 3, pp. 327-331, 2002.

[19] F. Katagiri, Y. Sato, H. Itoh, and M. Takeyama, "Cetraxate raises levels of calcitonin gene-related peptide and substance $\mathrm{P}$ in human plasma," Journal of Pharmacy and Pharmacology, vol. 56, no. 4, pp. 557-561, 2004.

[20] M. Takeyama, K. Kondo, Y. Hayashi, and H. Yajima, "Enzyme immunoassay of gastrin releasing peptide (GRP)-like immunoreactivity in milk," International Journal of Peptide and Protein Research, vol. 34, no. 1, pp. 70-74, 1989.

[21] T. Kitagawa, T. Shimozono, T. Aikawa, T. Yoshida, and H. Nishimura, "Preparation and characterization of heterobifunctional cross-linking reagents for protein modifications," Chemical Pharmceutical Bulluten, vol. 29, pp. 1130-1135, 1981.

[22] Y. Kinoshita, T. Inui, and T. Chiba, "Calcitonin gene-related peptide: a neurotransmitter involved in capsaicin- sensitive afferent nerve-mediated gastric mucosal protection," Journal of Clinical Gastroenterology, vol. 17, supplement 1, pp. S27-S32, 1993.

[23] P. Holzer, E. H. Livingston, A. Saria, and P. H. Guth, "Sensory neurons mediate protective vasodilatation in rat gastric mucosa," American Journal of Physiology, vol. 260, no. 3, pp. G363-G370, 1991.

[24] P. Holzer, "Neural emergency system in the stomach," Gastroenterology, vol. 114, no. 4, pp. 823-839, 1998.

[25] B. Fontaine, A. Klarsfeld, T. Hokfeld, and J. P. Changeux, "Calcitonin gene-related peptide, a peptide present in spinal cord motoneurons, increases the number of acetylcholine receptors in primary cultures of chick embryo myotubes," Neuroscience Letters, vol. 71, no. 1, pp. 59-65, 1986.

[26] P. M. Hellstrom, O. Soder, and E. Theodorsson, "Occurrence, release, and effects of multiple tachykinins in cat colonic tissues and nerves," Gastroenterology, vol. 100, no. 2, pp. 431-440, 1991.

[27] P. T. Schmidt and J. J. Holst, "Use of antagonists to define tachykininergic control of intestinal motility in pigs," Peptides, vol. 18, no. 3, pp. 373-379, 1997.

[28] J. C. Brown, "Presence of a gastric motor-stimulating property in duodenal extracts," Gastroenterology, vol. 52, no. 2, pp. 225229, 1967.

[29] N. Ling, R. Burgus, J. Rivier, W. Vale, and P. Brazeau, "The use of mass spectrometry in deducing the sequence of somatostatina hypothalamic polypeptide that inhibits the secretion of growth hormone," Biochemical and Biophysical Research Communications, vol. 50, no. 1, pp. 127-133, 1973.

[30] C. H. You, W. Y. Chey, and K. Y. Lee, "Studies on plasma motilin concentration and interdigestive motility of the duodenum in humans," Gastroenterology, vol. 79, no. 1, pp. 62-66, 1980.

[31] P. Thor, R. Król, S. J. Konturek, D. H. Coy, and A. V. Schally, "Effect of somatostatin on myoelectrical activity of small bowel," The American Journal of Physiology, vol. 235, no. 3, pp. E249E254, 1978. 

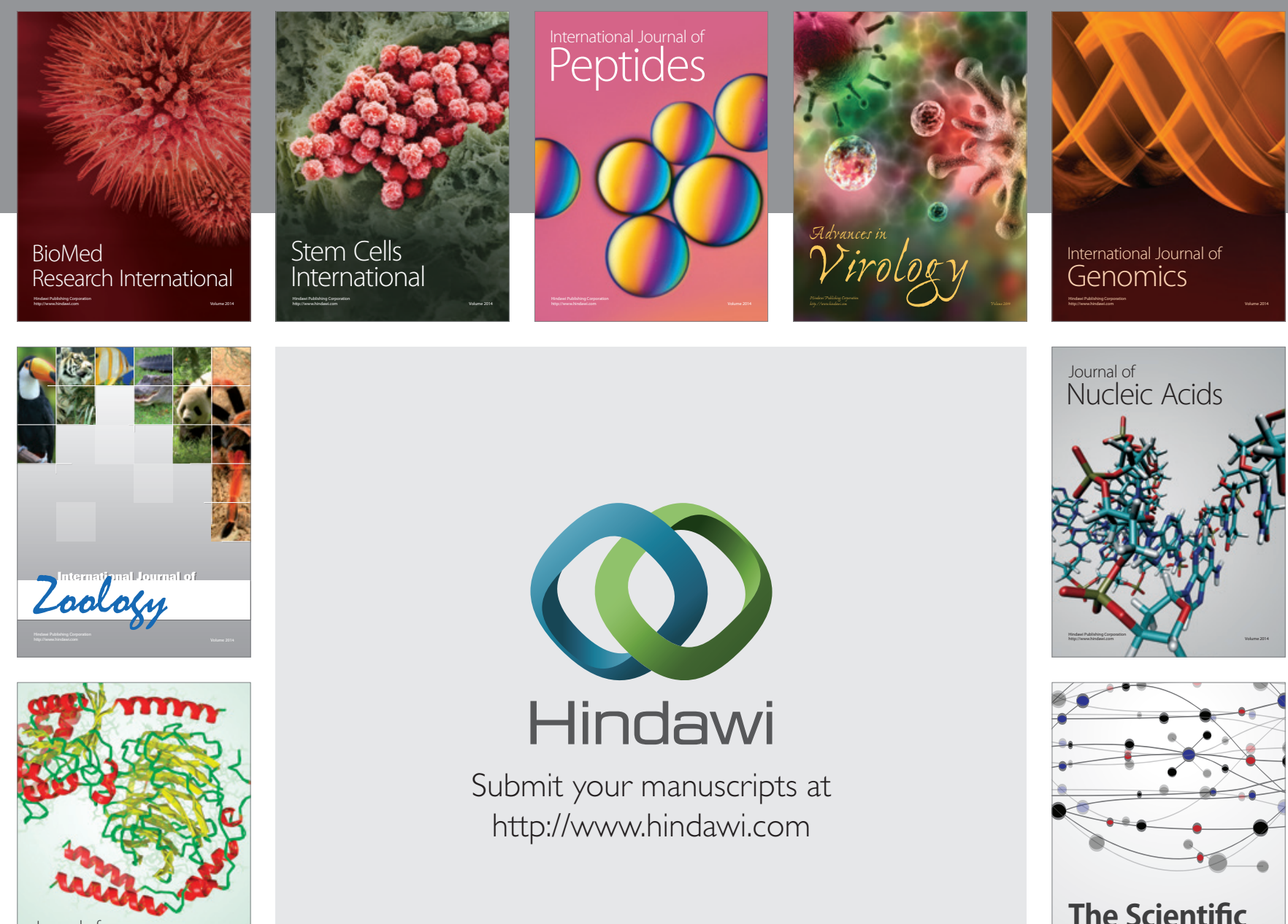

Submit your manuscripts at

http://www.hindawi.com

Journal of
Signal Transduction
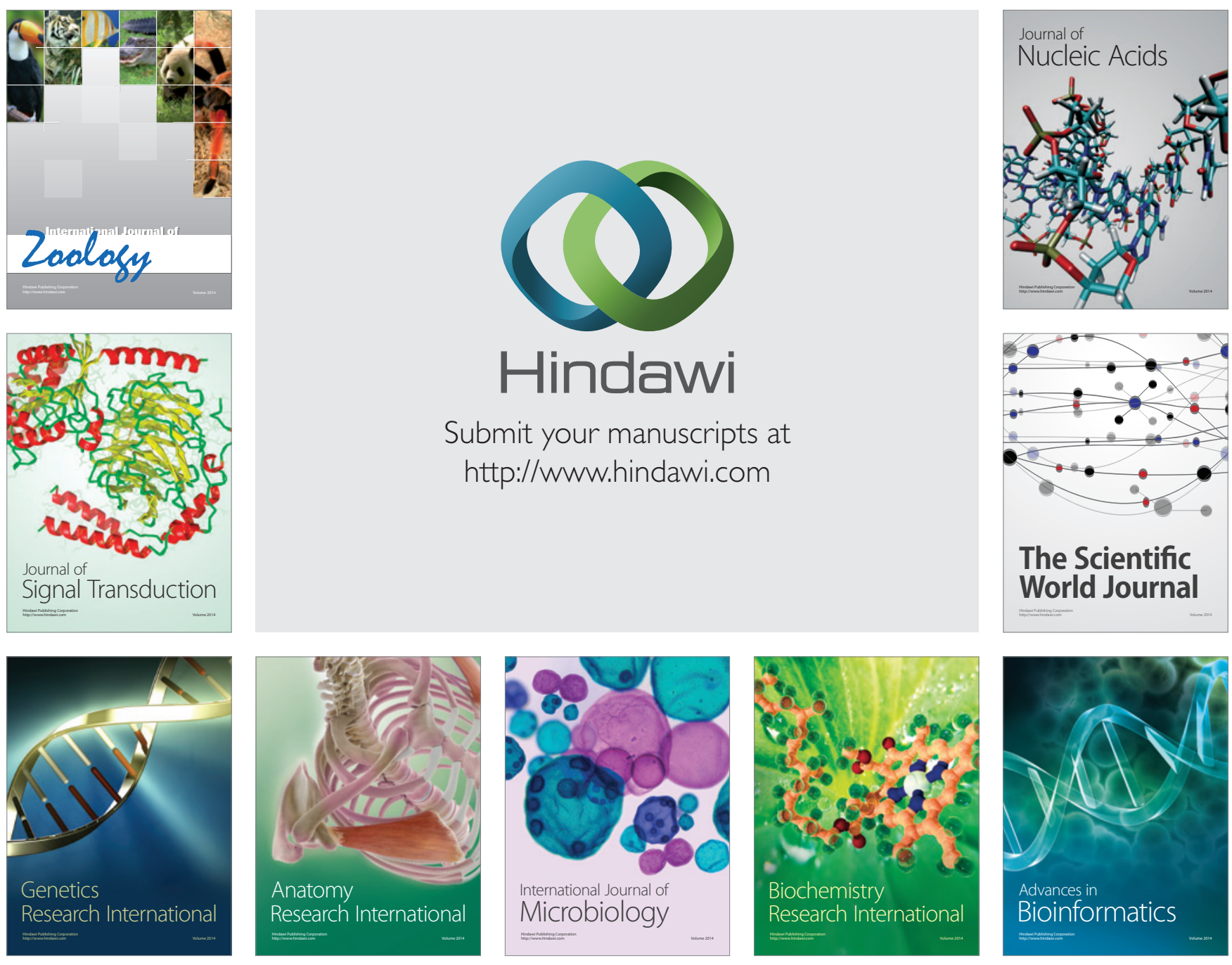

The Scientific World Journal
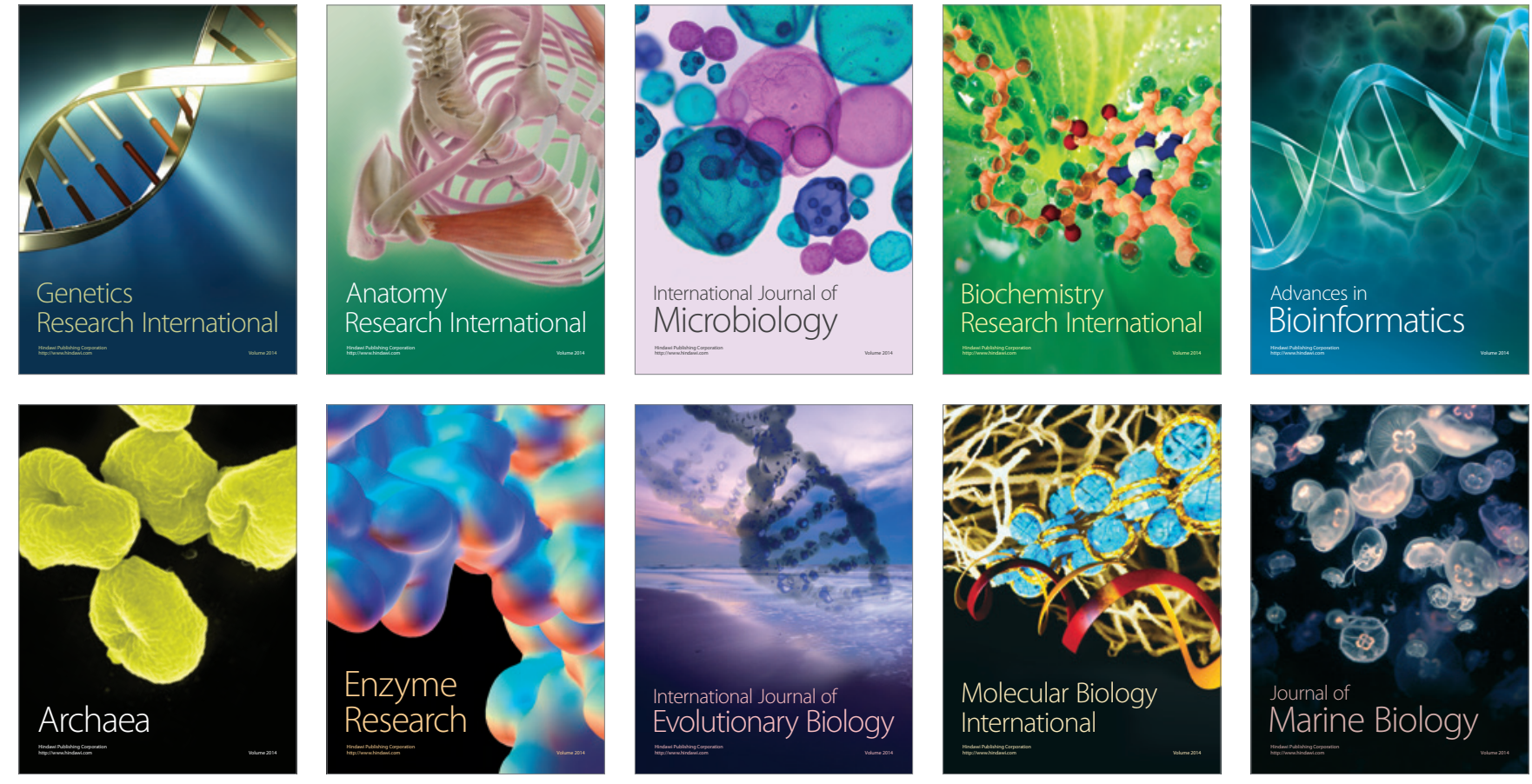